\title{
A Model of Friendly and Tolerant Community-Based School Mosque Management: Strategy Analysis and Empowerment
}

\author{
Imam Mawardi ${ }^{1 *}$, Akhmad Baihaqi ${ }^{1}$, Subur $^{1}$, Kanthi Pamungkas Sari ${ }^{1}$ \\ ${ }^{1}$ Faculty of Islamic Studies, Universitas Muhammadiyah Magelang, Indonesia \\ *Corresponding author.Email: mawardirazal@ummgl.ac.id
}

\begin{abstract}
The phenomenon of community-based school mosque (CBSM) becomes very interesting when it can contribute to community empowerment, both in the religious and social fields. The study aims to analyze an CBSM management model in Magelang City to spread the values of peace and tolerance for the school and the surrounding community. This research was carried out through a survey with the objects of the SMPN 2 (Junior High School) and SMAN 3 (Senior High School) mosques. The social phenomenology is used in this study which is combined with observation and in-depth interviews. The results show that the CBSM management model is based on the concepts of idarah, imarah, and ruayah, and it creates an inclusive school for community development. The programs of congregational prayers, recitation, zakat distribution, and sacrificial meat are used as the strategies in presenting a friendly and tolerant of Islam. Thus, CBSM management can contribute to emphasizes the social function of the school through the mosque and the peace of Islam, rahmatan lil alamin (Blessings for the universe).
\end{abstract}

Keywords: model of friendly, school mosque, management, empowerment

\section{INTRODUCTION}

Mosque has important roles for Moslems. Functionally, the mosque serves not only as a place for prayer, but a place for religious learning and social activities as well. This religious spirit leads to form a tradition pattern to build a mosque, not only among the community, but also covering in government offices, public service, including in educational institutions. Being formal educational institutions existing among the society, schools play significant roles to shape students' character and to develop noble values growing and developing in community's religious traditions. The character developed is the one portraying social ethics based on religious spirit. Therefore the school mosque functions as a forum to combine peaceful Islamic mission, full of tolerance between school residents and community, being the character contributing to community empowerment.

In reality, however, many school mosques are not yet properly functioned. There are many factors as obstacles, especially in connection with mosque management. This is a real problem that requires serious solution to develop appropriate model. Several studies have examined the school mosques, as carried out by Najib, who examines the school mosque as the character education laboratory[1]; Laugu, investigates several aspects that determine the significance of mosque libraries through history contributing to the development of Islamic civilization and also uncover factors contributing to the stagnation of mosque libraries [2]; Tamuri examines the innovation of increasing the role of mosques as an Islamic educational institution in the form of collaboration between schools, mosques and Moslem communities [3]; Ikhwan examines that the existence of mosques in general is one of the manifestation of Moslems' aspiration as the place for worshiping that occupy the central function, so that with this understanding, the strong belief emerges that the mosque is the center and source of Islamic civilization [4]; The strategy management and the performance of mosques in mosque management [5]. However, the research has not dealed with strengthening community-based mosque management when it is viewed from the strategies and systems implemented.

The results of previous research showed that all schools Magelang Municipality already have mosque serving as infrastructure for the needs of worship for school residents. Based on the usage school mosques are classified into three types, they are category A, B, and C. Firstly, Type A is school mosque used by school residents and the community together [6]. It is used not only to pray 5 times a day, but it is also used by the community for religious and social activities. Secondly, Type B is the school mosque used by school residents as a place of prayer for school residents at school and some people outside of the school hours. Type $\mathrm{A}$ and $\mathrm{B}$ school mosques are easily accessible to the community, and the position is located outside the school area. Thirdly, Type $\mathrm{C}$ is the school mosque which is only used for the needs of school residents. It is usually called "musholla". In this research, the focus is on the management of type A school mosques, they are SMPN 2 and SMAN 3 mosques, Magelang Municipality as development model that can be a reference in the development of school mosque management. This is because these two mosques have 
several advantages that are of particular value to the community.

For this reason, this study is intended to provide solutions to the need of developing CBSM management models to empower the function of the school mosque as the entity to socialize the values of peace and tolerance for the school community and the surroundings.

\section{METHOD}

This research was applied qualitative using an interpretative phenomenological analysis (IPA) approach with the target objects school mosques in Magelang Municipality has different characteristics than other school mosques [7]. The research focused on the SMPN 2 and SMAN 3 mosques. Both were chosen with the consideration that the school mosques are community-based school ones and have different characteristics from other school mosques. Data collecting was carried out through survey using observation method towards activities done in mosque management, and in-depth interviews were conducted to the mosque managers and worshipers, as well as the students who were active in Islamic extracurricular activity unit. To confirm the interview and observation data, Focus Group Discussion (FGD) was conducted to map the characteristics of mosque management. The data were then thematically analyzed based on the development of mosque management.

\section{RESULTS AND DISCUSSION}

\subsection{Functionalization of School Mosques: Educational and Social-Community Functions}

The result of school mosques mapping Magelang Municipality, shows that the mosques of SMPN 2 and SMAN 3 have uniqueness that are different from the ones in other schools, so that both are categorized in type A school mosque groups, the mosques serving as educational and social-community functions. First, the education function of school mosque is shown by the role of the mosque to shape the character of school residents, especially students to meet the spiritual attitude competencies required by formal curriculum. The spiritual attitude competence will strengthen the religious dimension as a basis to develop broader character of students' personalities. Characters developed at school consist of religious values, honesty, tolerance, discipline, hard work, creative, independent, democratic, curiosity, national spirit, love of the motherland, respect for achievement, communicative, love for peace, love to read, care about the environment, social care, and responsible; this is the manifestation of five interrelated main values; religiosity, nationalism, independence, mutual cooperation, and integrity, all of which are integrated in the curriculum [8]. Reinforcing the character at Junior High School level is certainly different from that of High School level. In SMPN 2 mosque-based character habituation is entirely controlled under the guidance and supervision of religious teachers, performing dhuha prayer activities, dhuhur prayers together (Friday), Quran reciting, and religious practice activities of Islamic Religious Education subjects. Other activities related to character building are conducted through activities of Commemorating Islamic Holidays (PHBI= Peringatan Hari Besar Islam), Ramadan in schools, distributing zakat fitrah, slaughtering and distribution of sacrificial meat, and so on. Strengthening character is also carried out through extracurricular activities by Islamic spirituality section for Moslem students.

In contrast to SMPN 2 of which students are early teenagers and mosque-based religious activities are still initiated by teachers; the students at High School level have sense of responsibility and independence attached on their own awareness. Although in terms of curriculum the development of religious character is integrated in Islamic Religious Education subjects, the school mosque serves as a laboratory for Islamic religious education, both related to subjects and activities managed by students of Islamic religious extracurricular units and the Intra-School Student Organization (OSIS). Religious studies and activities within the framework of the PHBI, as well as Ramadan activity are independently managed from students by students and for students under the guidance of religion teachers. It also includes the funding which is managed and independently initiated from student donations every Friday revolving in every classroom. In this case the school gives direction to keep running in accordance with the corridors and principles emphasizing the development of science, peace, and tolerance.

Second, the social-community function of the school mosque is carried out through community participation in school mosque-based activities. The main activity is the implementation of compulsory worshipers and other supporting activities, such as religious studies.

Masjid SMPN 2 is located on the right outside the school building and right at the T-Junction in the main road. Due to the strategic position the mosque becomes the stopover mosque during prayer times by people happened passing by. Islamic studies in the mosque of SMPN 2, are carried out in collaboration with the school and community in various forms of study, for example JIHAD MORNING (= Pengajian Ahad Pagi = Sunday Morning Study); this study is regularly managed by the community approved by the school and is conducted at 6:00 in the morning. Preachers (dai) presenting in the study are some Islamic public figures from outside the school. Besides, this mosque is often used for the activities of young people nearby who are gathered in Islamic Youth of Magelang to hold some Islamic and social study activities; for example, JUS MANGGA (Kajian Khusus Minggu Kedua=Second Week Special Study), KURMA Activities (Kelurga Rohis Magelang); They are the extracurricular activities of Islamic spirituality from schools throughout Magelang Municipality.

The mosque of SMAN 3 is located on the north side of the school yard and not far from Rejowinangun Market and the Chinatown Community. The population in this school area is mostly inhabited by Christians. Referring to the request of utilizing this mosque for prayer in congregation by Moslem residents around the school, SMAN 3 approves to sign agreement to maintain peace and mutual benefit of the 
school mosque. Good cooperation between the school and the community leads to activate and empower the school mosque by holding PHBI activities administered by the school. During Ramadan this mosque is full of activities with tarawih prayers and tadarus (Reading Quran). The school, yet, always tries to maintain harmony and tolerance for followers of other religions outside of Islam, and also controls activities that are actually counter-productive with friendly and peaceful Islamic teachings.

From the two functions of the school mosque, it can be understood that the mosque in its main function is as a place for Moslems to carry out religious rituals (worship) in performing the five daily prayers in congregation. The mosque is also a place to study knowledge, both religious and other science that is beneficial for life. Besides, the mosque also has social function packaged in interfaith gathering activities and social empowerment social activities, such as collection and distribution of zakat, infaq, shadaqah; distribution of sacrificial meat at the time of Eid al-Adha and so on. These are what has occurred in the mosques of SMP 2 and SMA 3, the functionalization of strengthening aqidah and ubudiyah which is an inherent obligation for school and community members does not ignore the meaning of Islam that is peaceful, harmonious and maintains highly tolerant values between Moslems and non-Moslem in the surroundings. The role of good management system from the school functions as the controller and supervisor for the possible impact of radicalism in the school mosque. Thus, the presence of the school mosque is blessings for human values.

The school mosque is the center for character education [9], specifically to strengthen spiritual and social attitude competencies for Moslem students. Strengthening religious character is the basis coloring the overall attitudes and actions of what is the orientation of the school mosque in shaping the character of Moslem personality. The character rooted from scientific spirits and supported by good management and the participation of the school community as well as the society to make the mosque prosperous is the distinctive excellence of the community-based school mosque.

\subsection{Model of CBSM Management: Strategies and Systems Empowerment}

Viewed from the strategies and systems developed, the model of CBSM management in SMP 2 and SMA 3 can be traced from the mosque management concept in general, although the implementation has not been optimally carried out. It is only based on habits that have developed as needed, and has not been well documented.

To map the system built in developing the CBSM model, it requires a management design pattern so that the strategy and system of mosque empowerment can be well arranged. Design patterns can be seen in Figure 1.

Management of the development of school mosques based on the model in Figure 1 cannot be separated from the strategy concept of idarah, imarah and ru'ayah. Idarah refers to an activity that involves planning, organizing, implementing, and monitoring. Imarah is the activity to make the mosque prosperous such as worship, education, social activities and commemoration of Islamic holidays, and some others. While ru'ayah is the activity to maintain building, equipment, tools, environment, cleanliness, and the beauty of the mosque, including the determination of qibla [10].

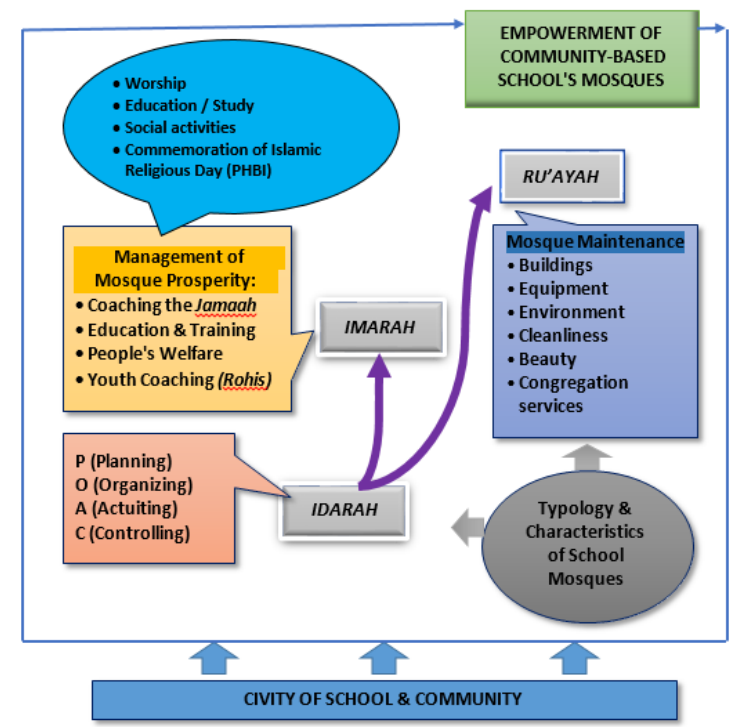

Figure1 Model of school mosque management

The idarah system determines the management of the school mosque to contribute to the empowerment of the mosque. The activity developed as an effort to empower the mosque can be done through several management activities, as explained in Table 1.

The imaroh system is carried out to strengthen the function of the school mosque to provide services to the prosperity of the mosque, especially the improvement of prayer services. The service related to education activities is realized to improve the quality of faith and piety through religious studies, so as to be able to foster religious awareness of school residents and the community of school mosque users. Social activities and commemoration of Islamic holidays are the leading program in community empowerment. Social activities are carried out through the distribution of zakat, tarawih and tadarus (reading Quran), tausiah (Islamic study) before the fasting break, slaughtering and distribution of sacrificial meat, etc. The same things happen to ruayah system as the effort to increase quantity and quality of main building as well as supporting facility such as cleanliness, beauty, and cozy atmosphere so that it will be attraction power for school residents and the community to prosper the mosque.

Due to the substance of the school mosque is not merely for the religious needs of school residents, but also for the community; then what is done by SMP 2 and SMA 3 Magelang City can be a pioneer model for friendly and tolerant school mosque Magelang Municipality and the surroundings. There is, of course, still much to improve in sustainable management system and strategy implemented. School mosques with community participation can foster inclusive attitudes in religion, so as to provide a sense of security, peace and tolerance towards adherents of other 
religions. That is the substance of the teachings of Islam that rahmatan lil'alamin (Blessings for the universe).

Table 1 Management system (Idarah)

\begin{tabular}{|c|c|c|}
\hline $\begin{array}{l}\text { Management } \\
\text { System }\end{array}$ & Indicator & Details \\
\hline Planning & $\begin{array}{l}\text { - Formulating the goals of the school mosque } \\
\text { activities to achieve. } \\
\text { - Determining a program of activities to achieve the } \\
\text { goals. } \\
\text { - Developing various alternatives in the } \\
\text { implementation of school mosque program } \\
\text { activities. } \\
\text { - Communicating the program of school mosque } \\
\text { activities. }\end{array}$ & $\begin{array}{l}\text { Planning is carried out by the mosque takmir } \\
\text { management based on the principal's policy proposed by } \\
\text { the teachers. } \\
\text { The activities are designed to meet the goals of the } \\
\text { school mosque out of the main prayer activities, but they } \\
\text { are related to the needs of developing the school mosque } \\
\text { empowerment. }\end{array}$ \\
\hline Organizing & $\begin{array}{l}\text { - Frame work is arranged based on the organizational } \\
\text { structure. } \\
\text { - Relationship within the organization is formal and } \\
\text { informal. } \\
\text { - The developed organizational systems are social, } \\
\text { functional, and communicative system. }\end{array}$ & $\begin{array}{l}\text { The organizational system runs in line with the cultural } \\
\text { mechanisms developing in each school. The structure of } \\
\text { the Mosque board members (Ketakmiran) refers to the } \\
\text { decree issued by the School Principal. }\end{array}$ \\
\hline Actuiting & $\begin{array}{l}\text { Religious and supporting activities are implemented } \\
\text { based on the planning. }\end{array}$ & $\begin{array}{l}\text { The implementation of activities is based on the planned } \\
\text { program by prioritizing the values of peace and } \\
\text { tolerance. Scheduling for muezzins, prayer leaders, } \\
\text { Friday sermons are well done. }\end{array}$ \\
\hline Controlling & $\begin{array}{l}\text { - Functionality of the mosque to the right target } \\
\text { according to the goal of the school mosque. } \\
\text { - Monitoring the implementation of the planned } \\
\text { program of activities. } \\
\text { - Avoidance from ideology leading to radicalism } \\
\text { through strengthening friendly and tolerant } \\
\text { character. }\end{array}$ & $\begin{array}{l}\text { The supervisory system is conducted by the school } \\
\text { principal, takmir management and marbot (someone } \\
\text { who is in charge of the mosque daily activity) over the } \\
\text { mechanism of implementing Islamic study activities by } \\
\text { considering the positive and negative impacts. The } \\
\text { emergence of obstacles can be anticipated in advance by } \\
\text { the inherent supervision of takmir administrators and } \\
\text { school principals }\end{array}$ \\
\hline
\end{tabular}

\section{CONCLUSION}

This research found a CBSM management model with a prototype of SMP 2 and SMA 3 mosque with a system developed from the concept of idarah, imarah and ruayah. The analysis of the findings is the functioning of the school mosque: (1) functioning as educational mosque, which has a role to shape the character of school residents especially students in the fulfillment of spiritual attitude competencies, and (2) social functions, providing an inclusive nuance for the development of friendly and tolerant society. This research contributes to, firstly, scientific development, specifically as material for the study of Islamic Education classes; secondly, it has positive impacts on the management of mosques in other formal schools in Indonesia. This study is the continuation of the previous research discussing the typology and characteristics of the school mosque, therefore there must be further study to develop the da'wah curriculum in the school mosque.

\section{ACKNOWLEDGMENT}

Great gratitude is addressed to DRPM Ministry of Ristekdikti RI for financial assistance in the field of PDUPT research in this second year; Muhammadiyah University of Magelang for the facilities provided to support this research; Principal of SMP 2 and SMA 3 with all school members who are the objects of research; and Islamic Education Study Program students who help finding data at the research location.

\section{REFERENCES}

[1] M. Najib, N. A. Wiyani, and Sholichin, "Manajemen masjid sekolah sebagai laboratorium pendidikan karakter bagi peserta didik," TA'DIB, vol. XIX, no. 01, pp. 85-110, 2014.

[2] N. Laugu, "THE ROLES OF MOSQUE LIBRARIES THROUGH HISTORY," Al-Jami'ah, vol. Vol. 45, no. No. 1, pp. 91-118, 2007.

[3] A. H. Tamuri, "A New Approach in Islamic Education : Mosque Based Teaching and Learning," J. Islam. Arab. Educ., vol. 4, no. 1, pp. 1-10, 2012. 
[7] P. J. Roller, Margaret R.; Lavrakas, Applied

[4] A. Ikhwan, "Optimalisasi Peran Masjid dalam Pendidikan Anak: Perspektif Makro dan Mikro," Edukasi, vol. 01, no. 01, pp. 1-16, 2013.

[5] A. Jaafar, “A Proposed Model for Strategic Management (SM) and Mosque Performance (MP) in Mosque Management," Int. J. Manag. Inf. Technol. Eng., vol. 1, no. (3), pp. 29-36, 2013.

[6] I. Mawardi, et.all., "Typology and characteristics of community-based school mosques in Magelang RayaINDONESIA: A study on Da'wah curriculum management model of rahmatan lil alamin," Int. J. Innov. Creat. Change., vol. 6, no. 1, pp. 40-59, 2019.
Qualitative Research Design: A Total Quality Framework Approach. New York: The Guilford Press, 2015.

[8] "Peraturan Menteri Pendidikan dan Kebudayaan RI No 20 Tahun 2018 Tentang Penguatan Pendidikan Karakter Pada Satuan Pendidikan Formal”.

[9] M. Najib, et.al, Manajemen Masjid Sekolah sebagai Laboratorium Pendidikan Karakter: Konsep dan Implementasinya. Yogyakarta: Gava Media, 2015.

[10] E. Suherman, Manajemen Masjid. Bandung: Alfabeta, 2012. 